\title{
Flavonoid-Rutin Effect to Blood Glucose Level and Pancreas Regeneration in Diabetic Rats
}

\author{
Iis Inayati Rakhmat* \\ Biochemistry and Biomolecular Department, Faculty of \\ Medicine \\ Universitas Jenderal Achmad Yani \\ Cimahi, Indonesia \\ *iis_inayati@yahoo.co.id
}

\author{
Euis Reni Yuslianti, Teja Koswara \\ Pathology Anatomy Department, Faculty of Medicine \\ Universitas Jenderal Achmad Yani \\ Cimahi, Indonesia \\ ery.unjani@yahoo.co.id, tejakosw@yahoo.com
}

\begin{abstract}
Diabetes mellitus is chronic metabolic disorder characterized by hyperglycemic state triggers by the formation of cells free radical. Rutin as a flavonoid or secondary antioxidant can increase insulin secretion and stimulate pancreatic progenitor cells. This study aims to analyze the effect of flavonoid-rutin to decrease blood glucose levels and pancreas regeneration in diabetic rats induced by streptozotocin. Research model was a laboratory experimental and total sample 25 experimental animals consisting of 5 groups those are negative control (NC), positive control (PC), Flavonoid-flavonoid-rutin 25mg/kgBW (P1), Flavonoid-rutin 50 mg/kgBW (P2), and Flavonoid-rutin $100 \mathrm{mg} / \mathrm{kgBW}$ (P3). The study was conducted for 17 days by examination of blood glucose levels and pancreas regeneration. Data were analyzed Anova and Duncan $(P<0,05)$. The results showed flavonoid-rutin $50 \mathrm{mg} / \mathrm{kgBW}$ can reduce blood glucose levels and regenerate the pancreas because has the ability to reduce free radicals that increase in conditions of hyperglycemia.
\end{abstract}

Keywords-diabetes, blood glucose, pancreatic regeneration, flavonoid

\section{INTRODUCTION}

Diabetes Mellitus (DM) is chronic metabolic disorder which is characterized by an increase in blood glucose levels caused by decreased of insulin production, insulin effectiveness, or both with the results in metabolic disruption of carbohydrate, protein, and fat [1-3]. The effect of an increase in chronic blood glucose levels could provoke not only the formation of free radicals, but also decreasing antioxidants level, which is called as stress oxidative. The formation of stressed oxidative can be prevented by antioxidants which could seizes the free radicals and prevents chained reactions caused by free radical, one of these antioxidants is Rutin. Rutin is a flavonoid derivatives compound that came from the condensation process between quercetin aglycone and rutinose [4,5]. Flavonoid-rutin's administration in diabetic rats could decrease the blood glucose level [6]. Flavonoids could regenerate pancreas in deficiency insulin and suppresses $\beta$ cell apoptosis $[7,8]$.
Rambutan honey $0,5 \mathrm{~g} / \mathrm{kgBW}$ is effective in lowering the blood glucose level in diabetic' rats induced by streptozotocin (STZ) although it has not clearly proven about the role flavonoid-rutin's component in rambutan honey to lowering blood glucose level [9]. Streptozotocin induction can damage pancreatic $\beta$ cells by alkylation of DNA [10].

\section{EXPERIMENTAL DETAILS}

\section{A. Materials and Procedures.}

The subject of study is Wistar rats (Rattus novergicus) aged 2-3 months and weighting around 200-250 gram and the object of research is flavonoid-rutin, obtained from Sigma-Aldrich Company. This study used a complete random design within 5 group divided into 1st group as negative control group, 2nd group as positive control group (which is induced by $35 \mathrm{mg} / \mathrm{kgBW} \mathrm{STZ}$ ), and 3rd group that are divided into three treatment groups, the first group as P1, given $35 \mathrm{mg} / \mathrm{kgBW}$ STZ with $25 \mathrm{mg} / \mathrm{kgBW}$ Flavonoid-rutin, next group as $\mathrm{P} 2$, given 35 $\mathrm{mg} / \mathrm{kgBW}$ STZ with $50 \mathrm{mg} / \mathrm{kgBW}$ Flavonoid-rutin and last group as P3, given $35 \mathrm{mg} / \mathrm{kgBW}$ STZ with $100 \mathrm{mg} / \mathrm{kgBW}$ Flavonoid-rutin.

Rat's acclimatized for around 7 days, given standard meal around $30 \mathrm{~g} / 250 \mathrm{~g}$ and water ad libitum. Place in the cage based on the next standard phase to make the rat became hyperglycemic by induction using STZ liquid through intraperitoneal (IP) and given Flavonoid-rutin $35 \mathrm{mg} / \mathrm{kgBW}$ of for 14 days and then $2 \mathrm{~mL}$ blood sample were taken and examined by using GOD-PAP method. Those rats' later euthanatized by using ketamine xylazine 10:1 then surgery and around $2 \mathrm{~mL}$ of blood were taken from the heart also pancreas removed in order to examined the histopathology of pancreatic. Rat's tissue fixation by using $10 \%$ buffer neutral formalin (BNF), ethanol absolute, xylol, paraffin, 99,5\% of glycerin, eosin solution, hematoxylin solution $[6,11,12]$.

Data analyze were using One Way Anova and Post Hoc Duncan Test to find the exact Flavonoid- rutin's effective dosage. This study has been approved by the Ethics Study 
Commission of Faculty Medicine's Padjadjaran University listed in number 21/UN 6. KEP/EC/2020.

\section{RESULTS AND DISCUSSION}

\section{A. Flavonoid-Rutin Effect to Blood Glucose Level After Streptozotocin Induction}

Flavonoid-rutin has potency in reducing the blood glucose level. Effect of Flavonoid-rutin administrations on the blood glucose level can be seen in Figure 1.

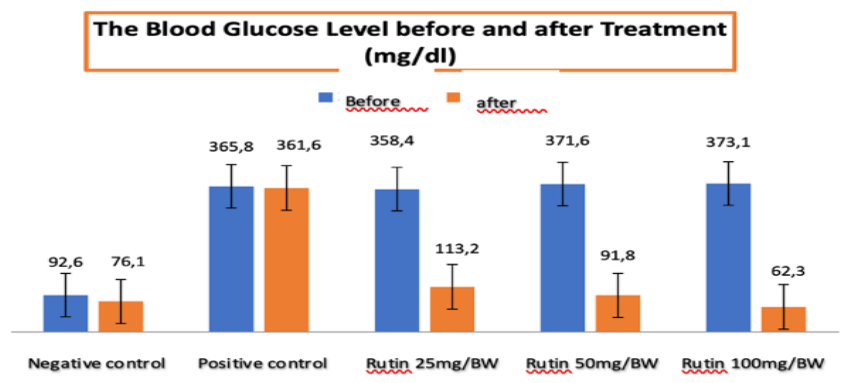

Fig. 1. Rutin effect on rats' blood glucose level.

The different between before and after flavonoid-rutin's administration on the blood glucose has shown on every group. Blood glucose level became lower event only with the dosage of $25 \mathrm{mg} / \mathrm{kgBW}$. It shows that low dose of flavonoid-rutin administration could lower the blood glucose level. To know the different of the blood glucose level reduction on each group was using One Way Anova test.

The result of One Way Anova Test was P-value $=0.000$ $(p<0.005)$, which means that the result of blood glucose level between at least 2 of 5 animal groups were significant. To knowing furthermore which group's that different than the others using pos hoc Duncan. The study result by using Duncan Test shows that $100 \mathrm{mg} / \mathrm{kgBW}$ dosage of flavonoidrutin placed in subset 1 , which means it could reach the normal blood glucose level, meanwhile $50 \mathrm{mg} / \mathrm{kgBW}$ dosage of flavonoid-rutin placed on subset 2 which means it almost reach the normal blood glucose level, therefore the conclusion about the most effective dosage is within $50-100 \mathrm{mg} / \mathrm{kgBW}$ to reduce the blood glucose level. This result was suitable with Niture in 2014 which explains that rutin administration with dosage between $50-100 \mathrm{mg} / \mathrm{kgBW}$ on diabetic rats could reduce the blood glucose level because Rutin as antiinflammatory agent that able to suppress the activity of TNF-a, IL-6, cytokines that related in insulin resistance and increasing the secretion of insulin that transform the calcium uptake on cell beta pancreas through intracellular transform and protein kinase-C (PKC) signaled pathway, also works as alfaglucosidase inhibitor that involved in activating hepatic enzymes that related to gluconeogenesis and suppressing the stress oxidative condition $[6,7,13]$.

\section{B. Flavonoid-Rutin Effect in Regenerating Pancreas After Streptozotocin Induction}

Flavonoid-rutin was able to give a good result in regenerating pancreas to find out the differences of pancreas regeneration in each group using One Way Anova Test because the data was normally distributed and homogenic.

The analytic result of One Way Anova Test shows there is a significant different on the evaluated pancreas regeneration with the $\mathrm{p}$-value of $0.035(\mathrm{p}<0.005)$. The study result shows that flavonoid-rutin could increase the wide of Langerhans island in each group $[8,10]$. To find out the flavonoid-rutin's dosage and to analyze the regeneration effect on Langerhans island using pos hoc Duncan test.

Post hoc test shows that group with dosage of $50 \mathrm{mg} / \mathrm{kgBW}$ (P2) and $100 \mathrm{mg} / \mathrm{kgBW}(\mathrm{P} 3)$ has better ability to regenerate pancreas. The wide of Langerhans island on P2 and P3 were showing the near normal size compare with the negative control group with normal size. However, on the dosage of 25 $\mathrm{mg} / \mathrm{kgBW}$ isn't enough to perfectly regenerate the pancreas. It means the greater dosage of flavonoid-rutin which were given more effective to regenerating pancreas. Its perhaps because the way how flavonoid-rutin works, catches ROS which has an ability to damages cell beta pancreas as anti-inflammatory that could stimulate the regulation of pancreas regeneration $[6,14]$.

Pancreatic histopathology is observed, focused on the wide of Langerhans island. In the day 14 of observation shows rat in group positive control has mononuclear cells. Its sign that there is an inflammation of pancreatic cell as the body's response against stress oxidative and infection [8]. The histopathology appearances could be seen in figure 2 .

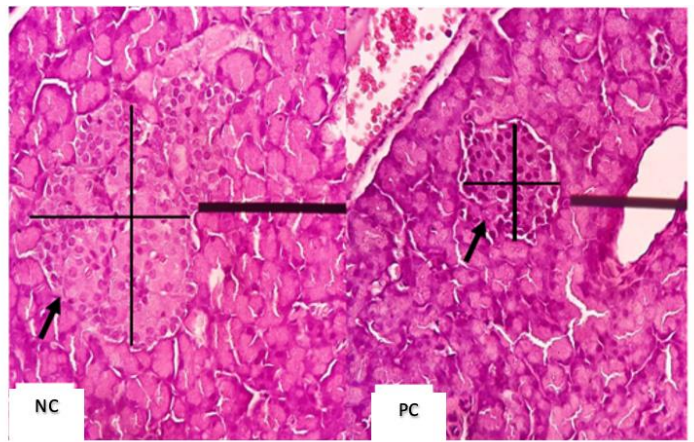

Fig. 2. Rat pancreatic histopathology after streptozotocin induction Magnification 400X, H\&E staining, (NC: negative control PC: positive control).

The result of microscopic observation on rat's pancreas were found that the average wide of Langerhans on positive control group is smaller compare with the negative control group $(42,7 \mu \mathrm{m} 2$ on positive control group, meanwhile its 98,1 $\mu \mathrm{m} 2$ negative control group).

Streptozotocin able to damages the pancreas cell through alkylating DNA. Streptozotocin result damages on the DNA's chain that turn into fragments, that causes damages on pancreas cell with smaller appearances of Langerhans island and also 
were found mononuclear cell as chronic inflammation cells [10].

The differences of flavonoid-rutin dosages have significant effect $(\mathrm{p}<0,05)$ on Langerhans island especially on the group with dosage of $50 \mathrm{mg} / \mathrm{kgBW}$ and $100 \mathrm{mg} / \mathrm{kgBW}$. Pancreas of diabetic rats which given $50 \mathrm{mg} / \mathrm{kgBW}$ dosage of flavonoidrutin shows that there were mononuclear cells found and Langerhans island appears smaller, meanwhile on diabetic rats that were given $100 \mathrm{mg} / \mathrm{kgBW}$ dosage of flavonoid-rutin, has a smaller number of mononuclear cells and Langerhans island appears bigger around $75,1 \mu \mathrm{m} 2$. The observation on pancreas regeneration marked with how large the representative of Langerhans island, on the rat's group which given treats shows that there is pancreas regeneration activity which marked with bigger Langerhans island (Figure 3).

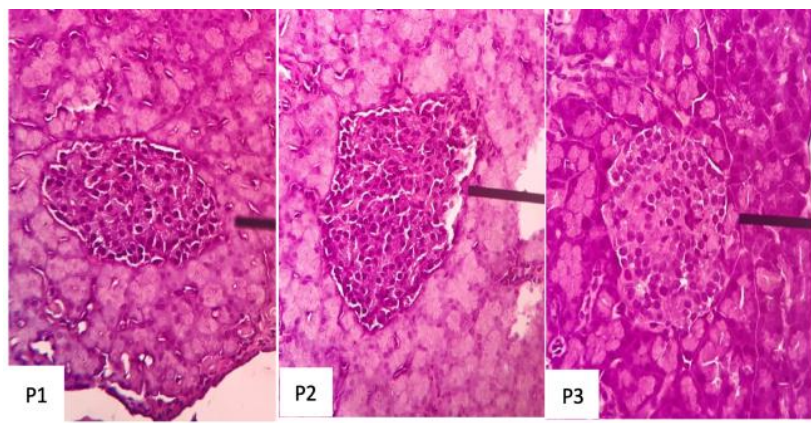

Fig. 3. Rat pancreatic histopathology after flavonoid-rutin therapy: Rutin 25mg/kgBW (P1), Rutin 50mg/kgBW (P2), and Rutin 100mg/ kgBW (P3). Magnification 400X, H\&E staining.

The healing process of damaged pancreas with therapy flavonoid-rutin shown more activity as seconder antioxidant. Activity of flavonoid-rutin antiinflammation could inhibit and stop damages on cell beta pancreas furthermore. The mechanism of flavonoid-rutin's function as antioxidant that could inhibit the DNA damage that caused by HO* reaction with nitrogen base DNA from streptozotocin. Therapy flavonoid-rutin shows that its stimulate the making of antioxidant enzymatic such as Superoxide dismutase (SOD), catalyst, and Glutation peroxidase (Gpx), this could protect the body cell especially cell beta pancreas in early apoptosis cell. Rifai's study in 2014 explains that flavonoid quercetin could regenerate the damaged pancreas cell, which none of infiltration of inflammation cell and increase the density of Langerhans island, where the flavonoid-rutin effect is to stimulate the progenitor cell on ductus pancreatic, so it could differentiate into new Langerhans island or endocrine cell on rats.8 This study was appropriate with experimental flavonoidrutin's test which part of flavonoid quercetin group. Flavonoidrutin prevents inflammation because it inhibits the building of cytokines proinflammation, such as TNF-a, IFN gamma, IL-1 and IL-6 which were able to induct apoptosis of cell beta pancreas through activating synapse between gen of cell beta under influence by transcription factor NF-kB of the healing cell beta pancreas wished could recover the normal function of pancreas, such as insulin production. The increased amount of insulin inside the body could increase the amount of glucose blood into cells $[15,16]$.

\section{CONCLUSION}

Flavonoid-rutin has effect in reducing the blood glucose level and regenerating pancreas cell. The next study hopefully could compare between antidiabetic drugs with flavonoid-rutin in order to regenerate pancreas cell.

\section{ACKNOWLEDGMENT}

This study supported by the Community Services Research Institute, Universitas Jenderal Achmad Yani Indonesia.

\section{REFERENCES}

[1] World Health Organization (WHO), Definition, Diagnosis, and Classification of Diabetes Mellitus and Its Complications. Geneva: WHO, 1999.

[2] Perkumpulan Endokrinologi Indonesia (Perkeni). Management and Prevention of Type 2 Diabetes Mellitus in Indonesia. (Perkeni). Indonesia, 2015.

[3] International Diabetes Federation (IDF), Diabetes Atlas. IDF, 2017.

[4] E.R. Yuslianti, Study of the potential of rambutan honey as a topical antioxidant for the healing of mouth mucosa wounds towards standardized herbal remedies. Jakarta: Universitas Indonesia, 2015.

[5] R. Vinayagam and B. Xu, "Antidiabetic properties of dietary flavonoids: a cellular mechanism review", Nutrition \& Metabolism, vol. 12, pp. 1$20,2015$.

[6] N.T. Niture, A.A. Ansari, and S.R. Naik, "Anti-hyperglycemic activity of Rutin in streptozotocin-induced diabetic rats: an effect mediated through cytokines, antioxidants and lipid biomarker", Indian J Exp Biol, vol. 52, pp. 720-27, 2014

[7] M.A. Abdelmoaty, M.A. Ibrahim, N.S. Ahmed, and M.A. Abdelaziz, "Confirmatory studies on the antioxidant and antidiabetic effect of Quercetin in rats", Indian Journal of Clinical Biochemistry, vol. 25, pp. 188-192, 2010.

[8] R.A. Rifaai, N. El-Tahawy, E.A. Saber, and R. Ahmed, "Effect of quercetin on the endocrine pancreas of the experimentally induced diabetes in male albino rats : a histological and immunohistochemical study”, J DiaMetab, vol. 3, no. 3, pp. 1-11, 2012.

[9] I.I. Rakhmat, E.R. Yuslianti, G.F. Permatasari, and T. Koswara, "Antihyperglycemic effect of rambutan honey in alloxan induced diabetic wistar rats", J. Pharmacol. Toxicol, vol. 12, no. 1, pp. 42-9, 2016.

[10] T. Szkudelski, "The Mechanism of Alloxan and Streptozotocin Action in B Cells of the Rat Pancreas”, Physiol Res, vol. 50, pp. 541-42, 2001.

[11] M. Muntiha, "Histopathological Preparation Techniques from Animal Tissue with Hematoxilin and Eosin Staining (H\&E)", Temu Teknis Fungsional Non Peneliti, pp. 157-162, 2001.

[12] T. Intan, W. Junus, P. Phetisya, and Octaviani, "Overview of Health in Mice (Mus Musculus) in Animal Installation Try", Jurnal Vektor Penyakit, vol. 8, no. 1, pp. 27-32, 2014.

[13] D.G. Gardner and D. Shoback, Lange Clinical Medicine: Greenspan's Basic and Clinical Endocrinology, 9th Ed. New York: McGraw-Hill; 2011, pp. 587-91.

[14] A. Marciniak, K. Brzeszczyńsk, and J.A. Gwoździński, "Antioxidant Capacity and Physical Exercise”, Biology of Sport; vol. 26, no. 3, pp. 198-204, 2009.

[15] Y. Guz, I. Nasir, and G. Teitelman, "Regeneration of pancreatic $\square$ cells from intra-islet precursor cells in an experimental model of diabetes", Endocrinology, vol. 142, no. 11, pp. 4596-4968, 2001.

[16] A. Noor, S. Gunasekaran, and M.A. Vijayalakhsmi, "Improvement of Insulin Secretion and Pancreatic $\beta$-cell Function in Streptozotocininduced Diabetic Rats Treated with Aloe vera Extract", Pharmacognosy, vol. 9, no. 1 pp. 99-104, 2017. 